\title{
4 Gender, ethnicity, and lived religion
}

\author{
Challenges to contextual \\ and liberation theologies
}

\section{Elina Vuola}

My long-term interest in and interaction with liberation theology and feminist theology has primarily focused on some theoretical and practical limitations in Latin American liberation theology from the perspective of feminist theology, and vice versa. ${ }^{1}$ Latin American feminist theology is not as known as it should be, either by feminist theologians from the Global North or by liberation theologians and feminist scholars from other fields in Latin America. At the same time, it is important to tell the narrative of feminist theology as a global, ecumenical, and interfaith movement. ${ }^{2}$

Since my early critique of the lack of sexual ethical thinking and practice in Latin American liberation theology, the situation has somewhat changed. While early Latin American feminist liberation theology did not engage with sexual ethics - especially Catholic sexual ethics - younger scholars have indeed taken up the challenge. ${ }^{3}$

Another research interest of mine has been the creation of more dialogue between feminist theology and gender studies in other fields. The problem of much of feminist theorising, in Latin America and elsewhere, has been a superficial and often non-existent interaction with and lack of knowledge of gender studies of religion, including feminist theology. In fact, feminist theology has been a ground-breaking field within gender studies in engaging with women and feminist thought of the Global South. ${ }^{4}$

Thus, the development and contemporary situation of global feminist theology looks somewhat different when analysed internally as a theological endeavour, on the one hand, and when analysed in relation to the broader development of gender theorising, on the other hand. This interdisciplinary challenge is still at the heart of any coherent understanding of liberation theology, globally and in all its forms, which includes feminist theologies and, to some extent, contextual theologies.

In this chapter, I will continue from my earlier research by asking what the pressing challenges of liberation and contextual theologies are today. I rely on my earlier research, aiming to discuss it in the context of this book. My aim is primarily theoretical. By that, I do not mean a juxtaposition of theory and practice. Rather, I ask what some contemporary theoretical developments in the study of religion and other fields relevant to liberation 
theologies would mean for the development of a liberation (contextual) theology, which does not have women, indigenous people, and other groups at the margins of critical theological thought. Obviously, this means also clarifying the relationship between liberation theologies, contextual theologies, and feminist theologies. For example, is gender a "context"? How are gender issues related to "culture"? How much has the expansion of subjects in liberation and contextual theologies really affected them - or has it? One possibility for thinking about these questions is the perspective of lived religion, which has become a major theoretical way of thinking about what is meant by "religion" and, especially, how to understand it from the perspective of marginalised and subjugated groups of people.

To sustain my more theoretical perspectives I will offer empirical examples from my own research on the meaning of the Virgin Mary for women in two different cultural and religious contexts (Costa Rica and Finland; Catholicism and Orthodoxy), on the one hand, and my ethnographic work among the Finnish Skolt Sámi, on the other hand. These two empirical works are related: my interest in both has been to expand the notions of the meaning of religious traditions for people (women, and ethnic and racial minorities) who have not been considered as theological subjects in their own right even in most liberation and contextual theologies. Further, research on indigenous people and their religious traditions, including various branches of Christianity, has usually not been linked to theological issues or theology as a discipline - possibly with the exception of missiology and mission studies, but certainly in the case of liberation, contextual, and feminist theologies. Finally, in order for any theology to be "global", it is important to draw from different cultural contexts, from both the Global South and the Global North. Neither is monolithic, or culturally or religiously singular, and in both, it is women who struggle to be recognised as subjects, including theologically.

\section{Lived religion and liberation theologies}

During recent decades, the perspective of lived religion has been influential in the study of religion, especially sociology of religion. Scholars of lived religion have focused on ordinary (lay) people and their ways of being religious and practising religion. ${ }^{5}$ Some of these scholars use the term everyday religion (Ammerman) or vernacular religion (Primiano). ${ }^{6}$ These terms are not entirely overlapping, but they share an interest in the ordinary, the margins, the everyday, and the material, and most of them also in gender. The different uses of the term reflect disciplinary differences: for example, Primiano is a folklorist, Ammerman a sociologist of religion, and Orsi a historian of religion. Methodologically, empirical work is at the heart of lived religion. At the same time, ethnographic work among ordinary people stresses their agency, instead of them being passive objects of religious knowledge and guidance from above. 
Nancy T. Ammerman has written a (self-)critical evaluation of the history and contents of lived religion. ${ }^{7}$ According to her, scholarship on lived religion has tended to focus too narrowly on certain geographical and cultural areas (mainly the United States) and religious traditions. Most of the publications on lived religion are written in English. The initial tendency of scholarship of lived religion to focus on the ordinary, the lived, instead of the official and institutional, has also led to an unnecessary binary between the institutional and the lived. In most religious traditions, especially in the Abrahamic religions, religion is lived at the intersection of these.

Written texts, their interpretation into doctrines, and how those affect the institutional are part of the lived experience and practice of the ordinary faithful, even when this relationship can be - and often is - contested. Liberation and feminist theologies, in my judgement, are good examples of how traditions, texts, and institutions are challenged and changed from the bottom up, even when the formulation of this critique is done primarily by academic theologians. The institutional and the doctrinal, too, are "lived". This is not usually taken into account in the scholarship of lived religion one reason being its meagre dialogue with theology and theologians. ${ }^{8}$

The challenge of liberation theologies is both theoretical and practical, even political. The self-understanding of all liberation theologies has been that liberation theology is "lived"; it stems from real circumstances of marginalisation and outright oppression. The liberation theological theoretical critique has challenged Euro- and androcentric interpretations of theology and their relationship to issues of power. As a result, contemporary theology and its repercussions in religious institutions and doctrines have been changed because of this critique - even if not enough. For example, the feminist critique of Christianity has been both theoretical and practical: explaining and questioning the image of women in the history, authoritative texts, and doctrine of Christianity, but also demanding concrete changes in the exclusion and marginalisation of women in Christian churches. This feminist rewriting of Christian theology has been influential in all Christian churches, but it is primarily some Protestant churches which have been willing to draw practical consequences of it, whether in the area of ethics or priesthood.

Thus, various liberation theologies have also had an impact on the institutional and doctrinal. This is true also of the Catholic Church, although it has been - and still is - surprisingly resistant to feminist theology, in spite of the fact that most important feminist theologians are Catholic. It is important to pay attention to this influence of liberation theologies, because it highlights how institutions and the official are never entirely separated from the lived, the everyday, and the cultural, or from issues of power.

In textual religions, such as Christianity, changes in doctrine and interpretation of sacred texts are of direct practical importance, especially for people who have been excluded from positions of authority and right to interpretation. Feminist theology, probably more than any other form of liberation 
theology, has challenged traditional theology due to the simple fact that women are half of humanity and they have been the primary objects of gendered religious restrictions and teachings, even on issues which are relevant only for them, such as motherhood, pregnancy, and menstruation. Both "the lived" and the doctrinal and institutional change, even if slowly, when tradition is reinterpreted and challenged by women.

A further potential restriction of the lived religion approach lies in its focus on the individual. This focus on individual people's thoughts, practices, and interpretations, as important as it is, may lead the lived religion approach to another binary between the communal and the individual. Even individual experiences are never detached from culture, tradition, and community. This is related to the previously mentioned relationship between the institutional and the lived.

Latin American liberation theology has since its beginning claimed that its roots are in la religiosidad popular (popular or folk religion) of Latin American people. Latin American Catholicism has since the early days of the Conquest been fused with indigenous religions and later with Africanbased religions. Thus, the liberation theological interest in la religiosidad popular may be interpreted as coming close to what is called lived religion. In Latin America, it has meant the recognition of indigenous people, lay Catholics - including women - and Afro-Latin Americans.

However, as I have argued elsewhere, Latin American liberation theology has failed in including indigenous, gender, and ecological concerns in its theoretical and practical core. ${ }^{9}$ This is largely due to a lack of applying the critique expressed by the corresponding social movements, which demand concrete political changes at the intersection of race, gender and sexuality, class, ethnicity, and ecology. In gender issues, particularly, liberation theology did not explicitly distance itself from racist and sexist elements of Christian (Catholic) theology. ${ }^{10}$ The importance of la religiosidad popular was emphasised in liberation theology, but without adequate and in-depth knowledge of indigenous spiritualities, popular Catholicism and Afro-Latin American religions.

Ethnographic methods have not been widely used in either feminist or liberation theology. The focus has been primarily on doctrinal and philosophical issues. Nor has there been much dialogue with anthropology or sociology of religion, not to mention gender studies. There is a broader under-development or even lack of religious studies in Latin American universities. Thus, the issue is also of somewhat narrow multidisciplinarity at the heart of liberation theological claims.

Some Latin American feminist theologians have proposed that their theology stems from la vida cotidiana, which could be translated as "everyday life" ${ }^{11}$ This, again, comes close to what is called lived religion in the AngloSaxon world. However, these possible antecedents of and overlappings with lived religion are not taken into account in standard presentations of lived religion. 
This is for at least two broad reasons: first, the already mentioned lack of knowledge and dialogue with theology, whether from the Global North or South, and second, the geopolitics of knowledge, ${ }^{12}$ which tends to universalise from theoretical traditions of the Global North, especially the United States, without recognising even influential traditions of thought elsewhere, such as liberation and contextual theologies.

I argue that the perspective of what is called lived religion has been and is in many ways present in feminist and liberation theologies, but whereas scholars of lived religion use primarily ethnographic methods (but, as said, may arbitrarily exclude the importance of theology), liberation theologies have - in a way contradictorily - focused on doctrine. Claims about the importance of indigenous spiritualities and women's interpretations remain superficial if they are not based on detailed scholarship done in these areas. At the same time, liberation and feminist theologies have opened up entirely new ways of thinking about theology and its subject. The "adding model" (of women, indigenous people, etc.), however, does not develop these theologies further if their central arguments and claims are not taken seriously and integrated at the core of theology. ${ }^{13}$ This need is as challenging for liberation theologies as it is for any other form of theology.

A greater use of ethnographic methods and interaction with such scholarship which allows issues related to gender, race, and ethnicity to be explained and understood - which includes showing how they are intertwined - would both take liberation theologies to new avenues of development and stay faithful to their original radical thought of changing the subject of Eurocentric, patriarchal theology.

\section{Contextual and liberation theologies}

What exactly is the difference between contextual and liberation theologies? ${ }^{14}$ They are sometimes presented as overlapping, often not, and at the least they have different emphases. Contextual theologians often remind us that all theology - and in the end, all human activity - is always contextual. Theoretically, this comes close to the emphases in other fields of research, which argue for the importance of positionality. It has been especially influential in cultural studies and gender studies: the possibility of stronger objectivity is anchored in the consciousness and reflection of the scholar of her/his cultural, racial, ethnic, and gendered position. In contextual theologies, the context - however defined - is the conscious point of departure for theological reflection: the context is defined, explicated, and reflected on in relation to other forms of theology. In contextual theologies, the context is often that of a subjugated or marginalised group. In this respect, they come close to liberation theologies: the context is not just something to be taken into account, but also to be changed.

For example, Stephen Bevans seems to understand contextual theology as somewhat overlapping with liberation theology. According to him, contextual 
theology can be defined as a way of doing theology in which one takes into account the spirit and message of the Gospel, the tradition of the Christian people, the culture in which one is theologising, and social change in that culture, including struggles for equality, justice, and liberation. ${ }^{15}$ His very broad definition includes a variety of ways in which contextualisation happens.

A culturally anchored approach would consider culture as a context: there is necessarily no political or other demand for change, but rather a conscious reflection on the Christian tradition from the perspective of other cultural realities than that of early Christianity and later that of its European developments. However, from the perspective of anthropology and cultural studies, it is difficult to consider any culture as monolithic or homogenous. Thus, when culture is taken as a point of departure, there is also a need for a more varied and detailed understanding of culture, including issues of historical changes, constellations of power, and heterogeneity within any given culture (e.g. gender, ethnicity). This is also what Bevans seems to be pointing at: the "context" or the "culture" is never neutral or homogenous, and within them, there are all kinds of inner variations and issues of power: cultures are not static. ${ }^{16}$

The history of Christian mission and the expansion of Christianity to other parts of the world, as well as the overlapping of this enterprise with European colonialism, are central points of reference. Here, culturally oriented contextual theologies again may come close to liberation theologies and their more explicated demands for change. Christianity arrived in what today is understood as the Global South intimately tied to the colonial interests and structures of Europe. The Christian message - interpreted and transmitted through European culture - was proclaimed as the universal truth. Contextual theologies have questioned and challenged this universality.

Contextual and liberation theologies are thus closely related, yet different. In both, critical de- and reconstruction of the Christian tradition and legacy is central. The locus and subject of traditional theology are consciously shifted in both, often with an emphasis on marginality, otherness, and subjugation. Feminist theologies bring yet another aspect to both contextual and liberation theologies by also challenging their androcentrism. However, it is difficult to consider race, gender, or ethnicity as a "context" in the sense in which it is usually understood in more culturally inclined contextual theologies. Similarly, ecotheologies are difficult to place adequately into either group, although it can be argued that both liberation and contextual theologies have a close methodological affinity to ecotheology and ecofeminist theology. Finally, if all theology has a context, it can be argued that there can be contextual theologies which can theologically and politically be in direct contradiction with liberation and feminist theologies. Thus, I prefer to use the term contextual theology of those theologies which share at least some basic tenets of the liberation theological impetus and which are also sensitive to gender issues and willing to consider feminist theology as a central part of their self-understanding. 


\section{Elina Vuola}

\section{Global feminist theology}

The issue of gender becomes particularly crucial when theologians take (their) culture as a point of departure. As previously stated, the presentation of any "culture" is intrinsically tied to issues of historical and contemporary power. In both liberationist and very conservative, even fundamentalist, contexts, women may be seen as primordial carriers of culture, on the one hand, and changes in their position as a threat to that culture, including religion, on the other. Contextual and liberation theologies need to be especially alert in mainstreaming gender in detailed ways, relying on adequate scholarship, in order to avoid such presentations of culture that principally harm women and in which women's roles and position are not taken into account. The same is true of issues of race and ethnicity: women and indigenous people may become both excluded in their own right and romanticised as the primary carriers of culture. ${ }^{17}$

Another kind of lack or meagreness of deep multidisciplinarity which affects the development of adequate gender theorising in the context of religion is between feminist study of religion - including feminist theology and other fields of gender research. An important part of my scholarship has focused on this lack of interaction between various forms of feminist theorising in different disciplines, which is especially striking when it comes to religion. This is true also of Latin American gender studies. ${ }^{18}$

Gender issues when related to religion may thus be ignored in both "secular" gender studies - even when making claims about the relationship between women and their religious traditions - and in contextual and liberation theologies, if there is not enough knowledge of and dialogue with the vast field of gender studies in religion. This includes feminist theology and the empirical, lived religion type of research on the variety of ways women interpret and live their religious traditions in different parts of the world.

The term "intersectionality" has become a major theoretical way to conceptualise gender. ${ }^{19}$ Today, it is a standard way in gender research to theorise on and understand how gender is always construed in relation to other differences and hierarchies of power, such as class, ethnicity, race, and sexual orientation, to name the most often used categories. Religion, by and large, has not been substantially theorised as a difference, and it may be difficult or even unnecessary to do so. However, religion crosscuts other differences, and is thus important to take into account. As a concept and way of taking a variety of crosscutting differences into account, intersectionality may possibly also serve a function in contextual and liberation theologies. Further, intersectionality theorises similar questions in gender studies and feminist politics to those that most liberation and contextual theologies do in theology and the study of religion.

Unfortunately, gender remains an issue to be mentioned but not adequately theorised in most contextual and liberation theologies. Similarly, religion has been - and, by and large, still is - an area of study that standard gender 
studies do not take into account. Gender scholars of religion, whether theologians or sociologists of religion, are thus not dialogued with in substantial enough ways to change the way we conceptualise both gender studies and liberation and contextual theologies. In Latin America, feminist liberation theologians' work is seldom quoted or recognised by gender scholars in other fields $s^{20}$ or the first generation of male liberation and contextual theologians.

In a recent publication for a gender studies audience, I pointed out how religion has not been substantially engaged with in the field of feminist studies. ${ }^{21}$ In order to make my argument about the exclusion of religion - and the feminist study of it - more concrete, I analysed how the idea of intersectionality was employed in feminist theology much earlier than in other fields of feminist studies, even though it was not called intersectionality then.

In my article, I did a re-reading of feminist theology in order to show how, from the early 1970s, feminist theologians stressed the interstructuring of gender, class, colonialism, race, and ethnicity to emphasise their practical and theoretical cooperation with liberation and feminist theologians from the Global South. They did not use the concept of intersectionality, instead using interrelatedness or interstructuring, but conceptually, they meant the same.22

In feminist theology, this early emphasis on the "interstructuring of oppression" from both the Global North and the Global South was an outcome of its collaboration with liberation theologies. Already in the 1980s, there were Asian and African liberation theologies, Black theology in both South Africa and the United States, and feminist theologies in all those contexts. Early feminist liberation theologians stressed the interstructuring of gender, class, race, and ethnicity to emphasise the practical and theoretical cooperation and dialogue of liberation and feminist theologians from the Global North and the Global South. Feminist liberation theologians including womanist and mujerista theologians from the United States and feminist theologians from the Global South - were practically and conceptually linked to liberation theology even with their critical perspectives. Both colonialism, with its far-reaching consequences, and religion became crucial "intersections" of feminist theology of the 1970s. Feminist theology has been global, ecumenical, and interreligious, and it has influenced all other liberation and contextual theologies for a long time already. Feminist theology, thus, can be understood both as a central part of all liberation and contextual theologies and as a critique of them, which sometimes has meant distancing.

Since feminist theology can be understood both as a form of liberation and contextual theology and as a specific field of gender studies, it is important that feminist theologians are read and dialogued with in both. The too meagre and selective interdisciplinarity in theology as well as in gender studies too often leaves out the extensive body of work produced by feminist theologians globally. Any claims about women's relationship 
to religion in both fields must start with feminist theological work in order not to reproduce stereotypical and unfounded arguments - whether on religion in secular gender studies or on women in contextual and liberation theologies.

Further, not only intersectionality, but also lived religion, may prove to be a fruitful way to bridge the lacunae that exist between fields. For theologians, it means greater use of empirical and ethnographic research, whether done by others or by oneself. My critique of the stereotypical and faulty presentation of religion and religious women in much of Latin American gender studies led me to learn ethnographic methods. This step does not mean moving from textual to empirical methods, but rather emphasises the need for both. Since the feminist dislike of religion (especially Catholicism) in Latin America gained specific intensity in the case of the Virgin Mary, I decided to interview Catholic women myself, to ask them what the Mother of God means for them. This research I did in Costa Rica, where I had earlier lived and worked. The broad result of this research is that the women I interviewed presented views, experiences, and thoughts on the Virgin Mary which do not easily fit either the traditional Catholic or the secular feminist view of her. ${ }^{23}$

My Costa Rican interviewees' views reflected in many ways the kind of image of the Virgin Mary that has been brought forward in Latin American liberation theology: Mary as an ordinary campesina woman, poor and young, but who is also the Mother of the poor and the prophetess of the Magnificat. At the same time, there were deeply gendered aspects in my interviewees' Mariology and lived Marian piety that are not present in liberation theological interpretations of her. For example, women turn to Mary especially in situations and issues that have more urgency for them as women, such as birth, infertility, and miscarriage. My interviewees tended not to emphasise her virginity, or they offered non-physiological interpretations of it. Because of her gender, Mary was explicitly understood as someone closer to women and more understanding of them than God and Jesus, comprehended as male. ${ }^{24}$

Christian women's lived religion involves theological pondering and reflection. Also, in order to understand what they actually say, a theological analysis is central. This is why I argue that it is important to use both empirical and theoretical methods. Theology, too, is lived, as all contextual and liberation theologies make clear. Nevertheless, there has been not much ethnography in either contextual and liberation theologies or feminist theologies to sustain the more theoretical analyses. The lack of mainstreaming gender in most liberation and contextual theologies leads to an absence of women's (and other groups') lived religion. As said, the same happens albeit for different reasons - in much of gender studies, including in the Global South. I am thus proposing greater and deeper interdisciplinarity in both contextual theologies and gender studies. This can result in better theory - through the use of terms such as intersectionality - and better 
empirical claims - through the use of approaches such as lived religion. Theology, for its part, can fertilise other fields of study through its more historical, textual, theoretical, and doctrinal analyses.

\section{Indigenous people and liberation theology: the Skolt Sámi}

Finally, I will take another example of how ethnography could feed into contextual and liberation theologies or theology generally. Issues of ethnicity, at least in Latin American liberation theology, have suffered from similar superficiality and absence to gender issues. The claims made by liberation theologians about the importance of indigenous cultures and spiritualities and their view of liberation theology as being based on la religiosidad popular have usually not stemmed from ethnographic work - either the scholar's own or that of anthropologists. ${ }^{25}$ My broad argument about the need for greater interdisciplinarity in contextual and liberation theologies is similar in the case of issues of ethnicity to in the case of gender issues: the "inclusion" of women and indigenous people is not enough, and sometimes it can even be detrimental, especially when it happens at the level of generalisations and stereotypes.

The need I perceived for the use of ethnographic methods in the contexts of Latin American gender studies - particularly concerning claims about religion - led me to continue on the same path in my own cultural context, Finland. I interviewed Finnish Orthodox women on their relationship with the Mother of God. ${ }^{26}$

The Orthodox Church has a long history in Finland, which is geographically and historically between the East and the West. After World War II, Finland lost significant parts of its easternmost territories, including most of Karelia, where most Orthodox lived, to the Soviet Union. Over 400,000 Finnish Karelians became internally displaced people who were evacuated and resettled in other parts of Finland. Among them were about 55,000 Orthodox Christians, two-thirds of the Finnish Orthodox population at that time. The Finnish evacuees included 500 Skolt Sámi (sä’mmlaž in Skolt, kolttasaamelaiset in Finnish) from Pechenga (Petsamo) in the northeast.

The Sámi are an indigenous people that have historically inhabited northern Scandinavia and the Kola Peninsula. They are divided into several tribes, of which the Skolt Sámi is one. Their traditional home area, which includes Pechenga, is situated in the Northwestern Kola Peninsula. It is estimated that there are today about 1,000 Skolts, of whom about 600 are in Finland and the rest in Russia and Norway. Of the Finnish Skolts, today only a little more than half speak Skolt Sámi as their mother tongue. The Skolts are traditionally Orthodox by religion, Christianised in the 16th century by Russian monks. This, besides language, customs, and history, sets the Skolts apart from the rest of the Sámi, who are primarily Lutheran. They are thus a small minority within two minorities in contemporary Finland: within the 
Orthodox Church (linguistically and ethnically), and among the other Sámi (linguistically and religiously).

After Finland ceded Pechenga to the Soviet Union, the Finnish Skolt Sámi were resettled in three villages situated on different sides of Lake Inari. The Skolts lost access to their ancestral fishing and hunting grounds, which resulted in the disintegration of their traditional way of life. The Skolt Sámi culture has suffered severely from Finnish national assimilation policies.

As part of my broader research among the Finnish Orthodox women, I also conducted interviews among the Skolt Sámi. All of my 19 interviewees were women, and I originally asked them similar questions to my other Orthodox interviewees on the meaning of the Mother of God. However, it turned out that they did not speak so much about the Virgin Mary as they did about the overall meaning of the Orthodox tradition and Church for them as an ethnic minority. ${ }^{27}$ My work among the Skolt Sámi was a combination of theological and ethnographic work, which uses intersectional analyses and the perspective of lived religion.

Skolt Sámi culture is intimately connected with the Orthodox faith. Eastern Christian influences set Skolts apart from other Scandinavian Sámi groups, a difference that has historically been a source of discrimination within the wider Sámi community, as well. Orthodox evacuees, both Karelians and Skolts, experienced stereotyping, suspicion and hostilities from the majority Lutheran culture until at least the early 1970s. Other Sámi groups were converted to Lutheranism much earlier, which is a source of pain and trauma even today. Protestant Christianity was much more stringent with the Sámi and their pre-Christian belief system, considered pagan, than the Orthodox Church was in the areas where it was the primary form of Christianisation. In the case of Finland, this means both Karelia and the Skolt Sámi region. At the same time, the Skolt Sámi were also met with suspicion by the other Sámi because of their Orthodox faith and different language and customs.

However, the Orthodox tradition has facilitated the maintenance of a distinctive Skolt identity. The Orthodox Church and tradition are important for the Skolt Sámi. Particularly for many older interviewees, it was difficult to separate religion and culture, for "to be Skolt Sámi is to be Orthodox".

Indigenous theologies, primarily in North and South America, have until now not informed Sámi theologians, with some few exceptions of young theologians such as Helga West (Finland), Tore Johnsen, and Jorunn Jernsletten (Norway). In their work, they may rely on indigenous theologies elsewhere, but primarily on their own cultural heritage and the traumatic history of Christianisation of the Sámi tribes. Nevertheless, my interest here is to point out how the voices of indigenous people themselves, theologians or not, must inform any contextual, liberation, or feminist theology which claims to speak for the indigenous people or takes their spiritual traditions into account in a liberation theological agenda. 


\section{Conclusions}

What implications could these thoughts have for contextual and liberation theologies? First, ethnicity - just as gender - is not something to be listed in the long list of contexts and forms of oppression. Rather, it is at the very heart of any liberation or contextual theology. At the same time, the critical view of feminist and indigenous theology of the history of oppression and contemporary marginalisation is a challenge also to contextual theology. The kinds of intersectional differences and contemporary forms of lived religion mentioned in this chapter are important to take into account in such research in order to avoid generalisations and stereotyping. Similarly, sensitivity to intersectional differences and forms of power - whether based on gender, ethnicity, or religion - is necessary in any form of contextual and liberation theology which "adds" culturally and historically subjugated groups (such as women and indigenous peoples) to its subjects.

Second, it is important that there are adequately trained theologians who create knowledge from their own experiences, in their own words, and with all the demands they have for both states and churches. At the same time, it is as important that the knowledge and viewpoints of ordinary people, whether women or indigenous or both, are included in all works that claim to "include" them. Their voices have to be gathered by adequate and ethical forms of research.

Third, more theoretically, true inter- and transdisciplinarity is important. Theologians could dialogue much more with ethnologists, anthropologists, sociologists, and gender scholars in order not to make overly broad and generalised claims about women/gender or indigenous people. The crosspollination of different fields is particularly important for theologies which have contextuality, liberation, and equality at their centre. Besides factual knowledge, a deeper interdisciplinarity can provide new tools and methods for research. In this chapter, I have taken up two: lived religion from the study of religion, and intersectionality from gender studies. The combination of textual and empirical methods can enrich theology - and, again, this may be especially crucial for the future of contextual and liberation theologies.

Fourth and finally, many of the themes I have discussed in this chapter are already to some extent present in contextual and liberation theologies, if compared with more traditional forms of theology. They may thus turn out to be the sites par excellence in which to further challenge both theology and constellations of power in religious institutions, society, and the academy. That requires contextual and liberation theologians to also be attentive to their own positions (of power) and to those who critique them.

\section{Notes}

1 Elina Vuola, Limits of Liberation: Feminist Theology and the Ethics of Poverty and Reproduction (Sheffield and New York: Sheffield Academic Press and Continuum, 2002). 
2 Elina Vuola, "Religion, Intersectionality, and Epistemic Habits of Academic Feminism: Perspectives from Global Feminist Theology," Feminist Encounters: A Journal of Critical Studies in Culture and Politics 1, no. 1 (2017): Article no. 4, www.lectitopublishing.nl/Article/Detail/DBU1TOTH.

3 See for example Marcella Althaus-Reid, ed., Liberation Theology and Sexuality: New Radicalism from Latin America (London: Ashgate, 2006). On religiously legitimated sexual and gender-based violence, in an African context, cf. Chammah J. Kaunda's Chapter 3 in this volume.

$4 \mathrm{I}$ argue this in detail in Vuola, "Religion, Intersectionality, and Epistemic Habits of Academic Feminism".

5 Nancy T. Ammerman, "Lived Religion as an Emerging Field: An Assessment of Its Contours and Frontiers," Nordic Journal of Religion and Society 29, no. 2 (2016): 83-99; Nancy T. Ammerman, ed., Everyday Religion: Observing Modern Religious Lives (New York: Oxford University Press, 2007); David D. Hall, ed., Lived Religion in America: Toward a History of Practice (Princeton: Princeton University Press, 1997); Meredith B. McGuire, Lived Religion: Faith and Practice in Everyday Life (Oxford: Oxford University Press, 2008); Robert A. Orsi, "Introduction," in The Cambridge Companion to Religious Studies, ed. Robert A. Orsi (Cambridge: Cambridge University Press, 2012), 1-11; Robert A. Orsi, The Madonna of 115th Street: Faith and Community in Italian Harlem, 1880-1950 (New Haven: Yale University Press, 2010).

6 Ammerman, "Lived Religion as an Emerging Field"; Ammerman, Everyday Religion; Leonard Norman Primiano, "Vernacular Religion and the Search for Method in Religious Folklife," Western Folklore 54, no. 1 (1995): 37-56.

7 Ammerman, "Lived Religion as an Emerging Field."

8 Cf. also Mika Vähäkangas and Karen Lauterbach, eds., Faith in African Christianity: Bridging Anthropological and Theological Perspectives (Amsterdam: Brill, 2017), and Joel Robbins' forthcoming book on theology and anthropology.

9 Elina Vuola, "Latin American Liberation Theologians' Turn to Eco(theo)logy: Critical Remarks," in Religion and Ecology in the Public Sphere, eds. Celia Deane-Drummond and Heinrich Bedford-Strohm (London: T\&T Clark/ Continuum, 2011), 91-110.

10 See also Vuola, Limits of Liberation; Althaus-Reid, ed., Liberation Theology and Sexuality.

11 Cf. María Pilar Aquino, Nuestro clamor por la vida: Teología latinoamericana desde la perspectiva de la mujer (San José: Editorial DEI, 1992). English edition and translation: Our Cry for Life: Feminist Theology from Latin America, trans. Dinah Livingstone (New York: Orbis Books, 1993).

12 Walter Mignolo, “The Geopolitics of Knowledge and the Colonial Difference," The South Atlantic Quarterly 101, no. 1 (2002): 57-96.

13 See Vähäkangas' Chapter 13 in this volume.

14 Cf. also on this central question the chapters of Ulrich Duchrow (Chapter 5), Volker Küster (Chapter 12) and Mika Vähäkangas (Chapter 13) in this volume.

15 Stephen B. Bevans, Models of Contextual Theology, 2nd ed. (New York: Orbis Books, 1994), 1.

16 Ibid., 22.

17 Vuola, Limits of Liberation; Vuola, "Latin American Liberation Theologians' Turn to Eco(theo)logy."

18 See Elina Vuola, "The Exclusion of (the Study of) Religion in Latin American Gender Studies,” LASA Forum XLVI, no. 1 (2015): 17-19, https://forum. lasaweb.org/past-issues/vol46-issue1.php; and Elina Vuola, "Intersectionality in Latin America? The Possibilities of Intersectional Analysis in Latin American Studies and Study of Religion," in Bodies and Borders in Latin Americal 
Cuerpos y fronteras en América Latina, eds. Silje Lundgren, Thaïs Machado Borges, and Charlotta Widmark, Serie Haina VIII (Stockholm: University of Stockholm, 2012), 131-51. Portuguese translation: "Interseccionalidade na América Latina? As possibilidades da análise interseccional nos estudos latinoamericanos de religião," in Estudos feministas e religião: tendências e debates, eds. Sandra Duarte de Souza and Naira Pinheiro dos Santos (Curitiba: Prisma, 2014), 15-38.

19 See for example Avtar Brah and Ann Phoenix, “Ain't I A Woman? Revisiting Intersectionality," Journal of International Women's Studies 5, no. 3 (2004): 75-86; Kimberlé Crenshaw, "Demarginalizing the Intersection of Race and Sex: A Black Feminist Critique of Antidiscrimination Doctrine, Feminist Theory and Antiracist Politics," University of Chicago Legal Forum 140 (1989): 139-67; Jennifer C. Nash, "Re-Thinking Intersectionality," Feminist Review 89 (2008): 1-15; Nira Yuval-Davis, "Intersectionality and Feminist Politics," European Journal of Women's Studies 13, no. 3 (2006): 193-209.

20 See Vuola, "The Exclusion of (the Study of) Religion."

21 See my argument in detail in Vuola, "Religion, Intersectionality, and Epistemic Habits of Academic Feminism."

22 Rosemary Radford Ruether, New Woman, New Earth: Sexist Ideologies and Human Liberation (San Francisco: Harper \& Row, 1975).

23 See Elina Vuola, "Seriously Harmful for Your Health? Religion, Feminism and Sexuality in Latin America," in Liberation Theology and Sexuality: New Radicalism from Latin America, ed. Marcella Althaus-Reid (London: Ashgate, 2006), 137-62. Spanish translation: "Gravemente perjudicial para su salud? Religión, feminismo y sexualidad en América Latina y el Caribe,” Pasos 127 (2006): 14-25; Elina Vuola, "La Morenita on Skis: Women's Popular Marian Piety and Feminist Research of Religion," in The Oxford Handbook of Feminist Theology, eds. Sheila Briggs and Mary McClintock Fulkerson (Oxford: Oxford University Press, 2011), 494-524; Vuola, "Intersectionality in Latin America?"; and Elina Vuola, The Virgin Mary across Cultures: Devotion among Costa Rican Catholic and Finnish Orthodox Women (London: Routledge, 2019). In this chapter, I am not quoting the interviews I did in Costa Rica (2006-2007) and Finland (2013-2014). These are available in Vuola, The Virgin Mary Across Cultures; and Elina Vuola, "The Mother of God in Finnish Orthodox Women's Lived Piety: Converted and Skolt Sámi Voices," in The Oxford Handbook of Mary, ed. Chris Maunder (Oxford: Oxford University Press, 2019), 195-212. Here, I have a broader and more theoretical interest in the importance of lived religion and ethnographic work for contextual and liberation theologies.

24 See more on my interviews in Costa Rica in Vuola, "Seriously Harmful for Your Health?" and The Virgin Mary across Cultures.

25 See Vuola, "Latin American Liberation Theologians' Turn to Eco(theo)logy."

26 See the analysis of my work in both Costa Rica and Finland in Vuola, The Virgin Mary Across Cultures.

27 See Vuola, “The Mother of God in Finnish Orthodox Women's Lived Piety"; Andreas Kalkun, Helena Kupari, and Elina Vuola, "Coping with Loss of Homeland through Orthodox Christian Processions: Contemporary Practices among Setos, Karelians, and Skolt Sámi in Estonia and Finland," Practical Matters, June 11, 2018, http://practicalmattersjournal.org/2018/06/11/copingwith-loss-of-homeland-2/. 